\title{
Caprine and ovine Greek dairy products: The official German method generates false-positive results due to K-casein gene polymorphism
}

\author{
V. Tsartsianidou, ${ }^{*}$ D. Triantafillidou, $\dagger$ N. Karaiskou, ${ }^{*}$ P. Tarantili, $\dagger$ G. Triantafillidis, $\ddagger$ E. Georgakis, $\ddagger$ \\ and A. Triantafyllidis*1 \\ *School of Biology, Aristotle University of Thessaloniki, Thessaloniki 54124, Greece \\ †Thessaloniki Subdivision of General Chemical State Laboratory, Thessaloniki 54625, Greece \\ ‡MEVGAL SA Dairy Company, Thessaloniki 51100, Greece
}

\section{ABSTRACT}

Caseins are widely used for species identification of dairy products. Isoelectric focusing (IEF) of para-kcasein peptide is used as the official German method for the differentiation between caprine (isoform A) and ovine (isoform B) dairy products, based on their different isoelectric points. The discrimination between Greek goat and ewe dairy products using IEF has, however, been shown to be problematic because of the existence of the ewe isoform in milk from Greek indigenous dairy goats. This could be due to nucleotide polymorphisms within the goat $\kappa$-casein gene of Greek indigenous breeds, which alter the isoelectric point of the para-кcasein peptide and lead to false positive results. Previous DNA analysis of the goat $\kappa$-casein gene has shown high levels of polymorphism; however, no such information is available for Greek indigenous dairy goats. Therefore, 87 indigenous dairy goats were sequenced at exon IV of $\kappa$-casein gene. In total, 9 polymorphic sites were detected. Three nonsynonymous point mutations were identified, which change the isoelectric point of the goat para-k-casein peptide so that it appears identical to that of the ewe peptide. Ten composite genotypes were reconstructed and 6 of them included the problematic point mutations. For the verification of genetic results, IEF was carried out. Both goat and ewe patterns appeared in the problematic genotypes. The frequency of these genotypes could be characterized as moderate (0.23) to high (0.60) within Greek indigenous breeds. However, this is not an issue restricted to Greece, as such genotypes have been detected in various non-Greek goat breeds. In conclusion, IEF based on the official German method is certainly inappropriate for ovine and caprine discrimination concerning Greek

\footnotetext{
Received June 29, 2016.

Accepted December 20, 2016.

${ }^{1}$ Corresponding author: atriant@bio.auth.gr
}

dairy goat products, and consequently a new method should be established.

Key words: goat, $\kappa$-casein polymorphism, isoelectric focusing, species identification

\section{INTRODUCTION}

The importance of milk and dairy products for the human diet has led to the development of methods to detect possible adulterations in the dairy industry. In particular, the production of sheep and goat milk is of major economic importance, resulting from the widespread acceptance of traditional cheeses, especially those made from one pure species with Protected Designation of Origin (PDO) such as pure sheep or pure goat cheeses (Borkova and Snaselova, 2005; Zachar et al., 2011). The most common fraudulent practice is that of substituting high-value (ewe and goat) milk during technological processing with cow milk, which is lower in price and available in larger and constant quantities. The presence of goat milk in ewe milk is less common. However, substitution of ewe milk with goat milk often occurs in Mediterranean cheese manufacturing (Haza et al., 1999). Lately, an increase in pure goat milk products has occurred, and this has prompted an interest in authentication methods for such products. The replacement of one type of milk with another could also create problems related to frequent adverse reactions in humans toward some milk proteins (allergies or intolerance) or religious, ethical, and legal issues (Zachar et al., 2011).

Determination of dairy products' authenticity is often carried out by analysis of major milk proteins (Strange et al., 1992; Mayer, 2005). The principal methods are immunological (ELISA; Haza et al., 1999), chromatographic [hydrophobic interaction column (HIC), HPLC; Romero et al., 1996; Bramanti et al., 2003], and electrophoretic techniques [isoelectric focusing (IEF), capillary electrophoresis; Mayer et al., 1997). Caseins $\left(\alpha_{\mathrm{S} 1}, \alpha_{\mathrm{S} 2}, \beta, \kappa\right)$, which constitute $80 \%$ of 
milk protein content, are used widely to evaluate and differentiate dairy products (Kaiser and Krause, 1985). Many studies based on electromigration techniques have been carried out, such as IEF of $\gamma$ - and para-к-CN (Kaiser and Krause, 1985; Mayer et al., 1997), because protein separation according to isoelectric point (pI) is suitable for the analysis of caseins that form many genetic variants among and within species (Strange et al., 1992). Isoelectric focusing is the official German method [L01.00-39 ( $\S 64$ LFGB); German Central Food and Feed Law Book, 2005] for the differentiation of ewe

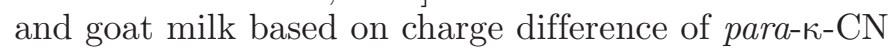
(Kaiser and Krause, 1985). The chymosin proteolysis of $\kappa-\mathrm{CN}$ results into a caseinomacropeptide and a

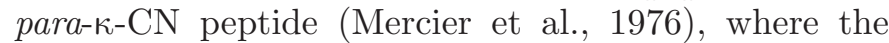
latter is the analyte used (Mayer et al., 1997). The 2 goat $\mathrm{k}-\mathrm{CN}$ protein variants, named $\mathrm{A}$ and $\mathrm{B}$ isoforms, were described by Di Luccia et al. (1990); Caroli et al. (2001) confirmed them via IEF. However, when 100\% goat cheese samples from Greece were analyzed across Europe using the official German method, they were misidentified as containing ewe milk. This substitution is, of course, unlikely, because ewe milk is much more expensive than goat milk. Research has shown that the discrimination, based on IEF, between Greek caprine and ovine dairy products is problematic, possibly because the goat $\kappa-\mathrm{CN}$ gene polymorphism leads to para$\kappa$-CN peptides identical to the ewe para- $\kappa-\mathrm{CN}$ peptide (isoform $\mathrm{B}, \mathrm{pI}=5.66$ ). As a result, the abundance of isoform $\mathrm{B}$ instead of $\mathrm{A}(\mathrm{pI}=5.29)$ in Greek goat cheese samples leads to false positive results, falsely identifying ewe milk (Triantafillidou et al., 2011; Supplemental Figure S1; https://doi.org/10.3168/jds.2016-11677).

The goat $\kappa$-CN gene has been studied and analyzed widely due to the important role of $\kappa-\mathrm{CN}$ in micelle formation, stabilization, and aggregation, which determine the technological and nutritional properties of milk (Moioli et al., 1998; Wedholm et al., 2006). Previous research has shown that the goat $\kappa-\mathrm{CN}$ gene, and specifically exon IV, is highly polymorphic. The segment which corresponds to the para-k-CN fraction revealed the majority of polymorphic sites (e.g., Coll et al., 1993; Caroli et al., 2001; Yahyaoui et al., 2001; Angiolillo et al., 2002; Prinzenberg et al., 2005; Kiplagat et al., 2010; Di Gerlando et al., 2015). Genetic analysis of this gene has not been carried out, until now, within Greek indigenous goats to identify possible point mutations. On the other hand, ewe $\kappa$-CN gene seems to be monomorphic (Moioli et al., 1998; Othman et al., 2013).

The aim of our study concerns the sequence determination and analysis of exon IV of $\kappa-C N$ gene from Greek indigenous goats, including the detection of (1) the variability found within the gene, (2) the nonsynonymous mutations that alter the isoelectric point of the para-k-CN peptide and complicate the differentiation between caprine and ovine milk by IEF, as well as (3) their allelic frequencies. Discussion of species identification methods also constitutes part of this work.

\section{MATERIALS AND METHODS}

\section{Animal Samples}

Eighty-seven goats (Capra hircus), belonging to the Greek indigenous breed, from 4 herds in northern Greece were analyzed. The selection of these specific herds is related to the high protein and fat content of their milk according to the breeders. Goat DNA was extracted from blood samples using a standard phenol-chloroform procedure (Sambrook et al., 1989). Thirty-two blood samples were collected from 2 herds in the prefecture of Thessaloniki, 29 blood samples from the area of Kilkis, and 26 blood samples from the area of Serres.

\section{Amplification of the Caprine $\mathrm{k}-\mathrm{CN}$ Gene}

A 645-bp fragment, including a part of intron 3 and the full sequence of exon IV (523 bp), of the goat $\kappa-\mathrm{CN}$ gene was amplified by PCR using a set of primers: I3F (5'-TCCCAATGTTGTACTTTCTTAACATC-3'; Angiolillo et al., 2002) and Kb2 (5'-GCGTTGTCCTCTTTGATGTCTCCTTAG-3'; Yahyaoui et al., 2001). The PCR reaction was performed in a $25-\mu \mathrm{L}$ final volume containing $1 \mathrm{U}$ of Taq DNA polymerase (Qiagen GmbH, Hilden, Germany), 1× PCR buffer, $0.25 \mu M$ each deoxynucleotide triphosphate (dNTP; Life Technologies, Rockville, MD), 50 pmol of each primer, and approximately $100 \mathrm{ng}$ of goat genomic DNA. Eppendorf 5331 (GE Healthcare Life Sciences, Pittsburgh, PA) thermal cycler conditions were adjusted to $95^{\circ} \mathrm{C}$ for 4 min, followed by 34 cycles of $94^{\circ} \mathrm{C}$ for $50 \mathrm{~s}, 56^{\circ} \mathrm{C}$ for 50 $\mathrm{s}$, and a final extension at $72^{\circ} \mathrm{C}$ for $1 \mathrm{~min}$.

\section{Sequencing and Sequence Analysis}

The PCR products were purified with PureLink PCR purification kit (Life Technologies) and sequenced by Macrogen (Tokyo, Japan) and Beckman Coulter Genomics (Danvers, MA) using the forward primer (I3F). The nucleotide sequences were analyzed by Geneious 8.0 (Kearse et al., 2012; http://www.geneious.com) and BioEdit v7.1.3 (Hall, 1999; http://www.mbio.ncsu.edu/ bioedit/bioedit.html) software. In addition, DnaSP software v5 (Librado and Rozas, 2009; http://www. ub.edu/dnasp) was used to reconstruct the nucleotide 
sequences of the heterozygous animals according to algorithms provided by PHASE v2.1 (Stephens et al., 2001), fastPHASE v1.1 (Scheet and Stephens, 2006), and HAPAR (Wang and $\mathrm{Xu}, 2003$ ). A Fasta format file including all the sequences was imported into DnaSP, where heterozygous nucleotide sites were substituted with IUPAC nucleotide code. The PHASE algorithm calculates the possible combinations of the polymorphic nucleotide sites to propose the reconstructed haplotypes and composite genotypes, taking into account homozygous individuals' haplotypes as well as their frequencies. The total number of reconstructed haplotypes was calculated using DAMBE software v5.3.10 (Xia and Xie, 2001; http://dambe.bio.uottawa.ca/DAMBE/ dambe.aspx).

\section{IEF}

The analysis of para-k-CN procedure was carried out according to the official German method L01.00-39 (§64 LFGB). Five milk samples were analyzed, corresponding to the observed genotypes I, II, III, IV, and VI. Casein samples isolated by the procedure of
Regulation 273/08 (Commission Regulation, 2008) from $100 \%$ cow milk cheese (market sample), from feta protected designation of origin cheese $(70 \%$ ewe, $30 \%$ goat; market sample), and the reference material CRM BCR 599 (which contains $50 \%$ ewe, $50 \%$ goat, and $0 \%$ cow), provided by JRC-IRMM (Joint Research Centre, Institute for Reference Materials and Measurements; European Commission's science and knowledge service), were used as controls. Additionally, a cheese produced from $100 \%$ goat milk and misidentified as adulterated (Triantafillidou et al., 2011) was analyzed (Supplemental Figure S1; https://doi.org/10.3168/jds.2016-11677).

\section{RESULTS}

\section{Nucleotide Sequences}

The sequence analysis of the amplified DNA fragment revealed the presence of 9 polymorphic sites within Capra hircus CSN3 exon IV (523 bp; Figure 1, Table 1). Six of the sites are located in the part of the gene encoding for the para- $\kappa-\mathrm{CN}$ peptide (144-470 bp) and the rest belong to the segment encoding for the

144 TGCTGTGAGAAAGATGAAGATTCTTCGATGACAAAATAGCCAAATATATCCCAATTCAG 203

245247

204 TATGTGCTGAGTAGgTATCCTAGTTATGGACTCAATTACTATCAACAGAGACCAGTTGCA 263

$284 \quad 309$

264 CTAAT TAATAATCAATTTCTGCCATACCCATATTATGCAAAgCCAGTTGCAgtTAgGTCA 323

324 CCTGCCCAAACTCTTCAATGGCAAGTTTTGCCAAATACTGTGCCTGCCAAGTCCTGCCAA 383

385

384GACCAGCCAACTACCCTGGCACGTCACCCACACCCACATTTATCATTTATGGCCATTCCA 443

471 (start of caseinomacropeptide)

444 CCAAAgAaAgATCAgGATAAAACAgAagTCCCTGCCATCAATACCATTGCTAGTGCTGA 503

550

504 CCTACAGTACACAGTACACCTACCACCGAAGCAATAGTGAACACTGTAGATAATCCAGAA 563

591

564 GCTTCCTCAGAATCGATTGCGAGTGCATCTGAGACCAACACAGCCCAAGTTACTTCAACC 623

624 GAGGTCTAAAAACTCTAAGGAGACATCAAAGAGGACAACGC

664

Figure 1. Analyzed segment (523 bp) of GenBank sequence with Accession No. X60763, which represents Capra hircus k-CN mRNA (826 bp) and corresponds to allele A. Polymorphic sites are shown in bold. The 3 nonsynonymous positions altering the isoelectric point of the caprine $\kappa-\mathrm{CN}$ gene product are underlined as well. 
caseinomacropeptide (471-664 bp). The AA positions corresponding to these nucleotide sites are 43, 44, 56, 65, and 90 for para-k-CN peptide and 119, 145, and 159 for caseinomacropeptide (Table 1).

Two nucleotide substitutions $(245,284)$ are silent mutations and have no effect on the primary structure of the protein. Three of 7 nonsynonymous mutations (247, 384, and 385) result in AA substitutions at positions 44 (Gln $\rightarrow$ Arg) and 90 (Asp $\rightarrow$ Asn, Asp $\rightarrow$ Gly) of the protein. These substitutions alter the $\mathrm{pI}$ of the caprine para-k-casein (Isoform A) and encode peptides with sheep-like IEF-phenotype (Isoform B). The mutation at position 309, although nonsynonymous, results in minor differences to the $\mathrm{pI}$ of the goat para- $\kappa-\mathrm{CN}$ peptide; therefore, the total para- $\kappa-\mathrm{CN}$ pI remains almost the same (Triantafillidou et al., 2011). Nonsynonymous mutations at 471,550 , and 591 positions belong to the caseinomacropeptide part and therefore do not affect

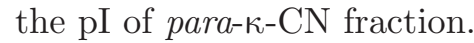

According to DnaSP software, the genetic profile of all 87 sequenced individuals is represented by 6 alleles (Table 2). The BLAST (https://blast.ncbi.nlm.nih. gov/Blast.cgi) tool was used to match these Greek goat alleles with possible $\kappa$-CN alleles that have already been identified in other European, African, and Asian goat breeds. These 6 alleles form 10 genotypes (Table 3). Genotypes II, IV, V, VI, VII, and IX include alleles 2,4 , and 6 , which carry isoform B-producing mutations in heterozygous condition (Table 2). Consequently, the observed genotypes should lead to the production of both peptides. Concerning the genotypes that lead to isoform B production, genotype II is the only one present in the 3 geographic areas sampled from northern Greece in frequencies ranging from 0.12 to 0.50 . All other (isoform B-producing) genotypes are found sporadically in low frequencies (Table 3; Supplemental Tables S1-S4; https://doi.org/10.3168/jds.2016-11677).

\section{Milk Samples - Electrophoretic Pattern}

To verify the production of isoform $\mathrm{B}$ from the problematic genotypes, IEF was carried out according to the official German method using 5 goat milk samples, which were predicted to produce either only isoform A or both isoforms (A and B patterns based on genetic analysis; Figure 2). Control samples with known cow, goat, and ewe milk content percentage were used to compare the protein bands. Additionally, a cheese produced from $100 \%$ goat milk and misidentified as adulterated (sample 10-11, Supplemental Figure S1; https://doi.org/10.3168/jds.2016-11677) using the official German method were analyzed.

Samples 6 and 10, corresponding to genotypes I (1/1) and III $(1 / 3)$, exhibited a single band, which is the expected goat para-k-CN band (isoform A). Samples 7,8 , and 9 , corresponding to genotypes VI $(2 / 3)$, II

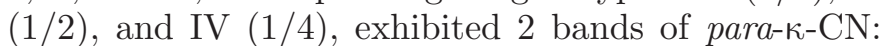
the goat para- $\kappa-\mathrm{CN}$ band (isoform $\mathrm{A}$ ) and an ewe-like para- $\kappa-\mathrm{CN}$ band (isoform B). Therefore, the heterozygosity revealed by sequence analysis is confirmed by the IEF analysis according to the official German method [L01.00-39 (§64 LFGB); German Central Food and Feed Law Book, 2005], where the genotypes predicted to be problematic produce electrophoretic patterns generating erroneous results concerning the species identity of the sample.

\section{DISCUSSION}

\section{Genetic Analysis of $\mathrm{K}-\mathrm{CN}$ in Greek Goats Compared with European Goats}

The $\kappa$-CN gene is considered as the most polymorphic among the 4 casein genes. Previous research has revealed high polymorphism for the goat $\kappa-\mathrm{CN}$ locus in

Table 1. Nucleotide point mutations ${ }^{1}$ and deduced AA substitutions

\begin{tabular}{|c|c|c|c|}
\hline Nucleotide position $^{2}$ & Type of mutation & AA substitution & IEF isoform \\
\hline \multicolumn{4}{|l|}{ Para-к-casein fraction } \\
\hline $245(\mathrm{~T} \rightarrow \mathrm{C})$ & Synonymous & $\mathrm{Tyr}_{43} \rightarrow \mathrm{Tyr}_{43}$ & A \\
\hline $247(\mathrm{~A} \rightarrow \mathrm{G})$ & Nonsynonymous & $\mathrm{Gln}_{44} \rightarrow \mathrm{Arg}_{44}$ & B \\
\hline $284(\mathrm{G} \rightarrow \mathrm{A})$ & Synonymous & $\operatorname{Leu}_{56} \rightarrow$ Leu $_{56}$ & $\mathrm{~A}$ \\
\hline $309(\mathrm{G} \rightarrow \mathrm{A})$ & Nonsynonymous & $\mathrm{Val}_{65} \rightarrow \mathrm{Ile}_{65}$ & $\mathrm{~A}$ \\
\hline $384(\mathrm{G} \rightarrow \mathrm{A})$ & Nonsynonymous & $\mathbf{A s p}_{90} \rightarrow \mathbf{A s n}_{90}$ & B \\
\hline $385(\mathrm{~A} \rightarrow \mathrm{G})$ & Nonsynonymous & Asp $_{90} \rightarrow$ Gly $_{90}$ & B \\
\hline \multicolumn{4}{|l|}{ Caseinomacropeptide } \\
\hline $471(\mathrm{~A} \rightarrow \mathrm{G})$ & Nonsynonymous & $\mathrm{Val}_{119} \rightarrow \mathrm{Ile}_{119}$ & \\
\hline $550(\mathrm{~T} \rightarrow \mathrm{C})$ & Nonsynonymous & $\mathrm{Val}_{145} \rightarrow \mathrm{Ala}_{145}$ & \\
\hline $591(\mathrm{~T} \rightarrow \mathrm{C})$ & Nonsynonymous & $\operatorname{Ser}_{159} \rightarrow \operatorname{Pro}_{159}$ & \\
\hline
\end{tabular}

${ }^{1}$ Point mutations in bold represent problematic AA substitutions leading to isoform change.

${ }^{2}$ Nucleotide positions are according to the GenBank sequence with Accession No. X60763, which represents Capra hircus k-CN mRNA. 


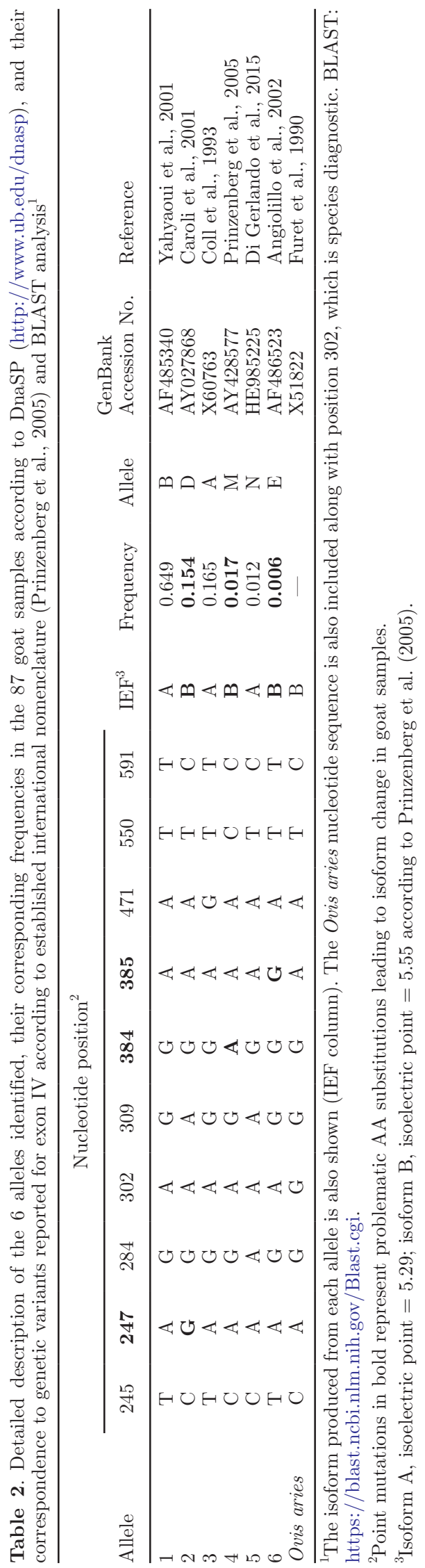

European, Asian, and African breeds. Thirteen variants at the protein level and 3 silent mutations have been identified for CSN3 (Di Luccia et al., 1990; Caroli et al., 2001; Yahyaoui et al., 2001, 2003; Chessa et al., 2003; Jann et al., 2004; Prinzenberg et al., 2005; Reale et al., 2005; Sacchi et al., 2005; Gupta et al., 2009; Kiplagat et al., 2010; Di Gerlando et al., 2015).

In our study, genetic analysis of the goat $\kappa$-CN gene among Greek indigenous dairy goats was undertaken for the first time in 87 samples from 4 herds in northern Greece. The analysis of a $523 \mathrm{bp}$ of exon IV of the $\kappa$-CN gene revealed the presence of 9 polymorphic sites (Figure 1, Table 1). No mutations other than those previously described for exon IV were detected.

Six alleles were reconstructed, with 3 of them occurring at higher frequencies compared with the rest (Table 2; Supplemental Tables S2-S4; https://doi. org/10.3168/jds.2016-11677). Allele 1 corresponds to allele B (Yahyaoui et al., 2001) and is the most prevalent (0.649) for the Greek breeds. As seen in other studies, CSN3 allele B is widely distributed in all European breeds genotyped so far, such as Italian (Chessa et al., 2003; Reale et al., 2005), French (Yahyaoui et al., 2001), Spanish (Yahyaoui et al., 2001), as well as African breeds (Kiplagat et al., 2010). Alleles 2 and 3 follow as the next most common alleles with very similar frequencies (0.155-0.166); allele 2 corresponds to allele D (Caroli et al., 2001) and allele 3 to allele A (Coll et al., 1993), respectively. Allele A of CSN3 is present in all European and non-European goat breeds, usually as the second most frequent. Allele D of CSN3 usually appears in low frequencies, usually in Italian breeds such as Cashmere (0.035), Girgentana (0.05), and Teramana (0.10; Yahyaoui et al., 2001; Reale et al., 2005). Alleles $\mathrm{M}, \mathrm{N}$, and $\mathrm{E}$ appear at very low frequencies in Greek as well as other goat breeds; however, allele E seems to be representative for the Italian goat breed Montefalcone (0.41, $\mathrm{n}=17$; Yahyaoui et al., 2001).

Comparing the genetic diversity of the Greek goat breeds with that of European and non-European breeds, we argue that they are quite similar concerning alleles and frequencies (Supplemental Tables S2-S4; https:// doi.org/10.3168/jds.2016-11677), excluding the high frequency of the CSN3 D allele among Greek indigenous breeds. Limited data have been published on the genetic diversity of the Greek goat $\kappa$-CN gene. Recent SNP analysis of the genetic profile of Italian, Albanian, and Greek goat breeds revealed that the Greek goat breed is closely related to Italian breeds. However, the Skopelos breed (not sampled in the present study) seems distant from the rest of the breeds, probably due to genetic drift phenomena, as it has been raised on an island (Pariset et al., 2009). Additional analyses are needed on the genetic structure and affinities of the 


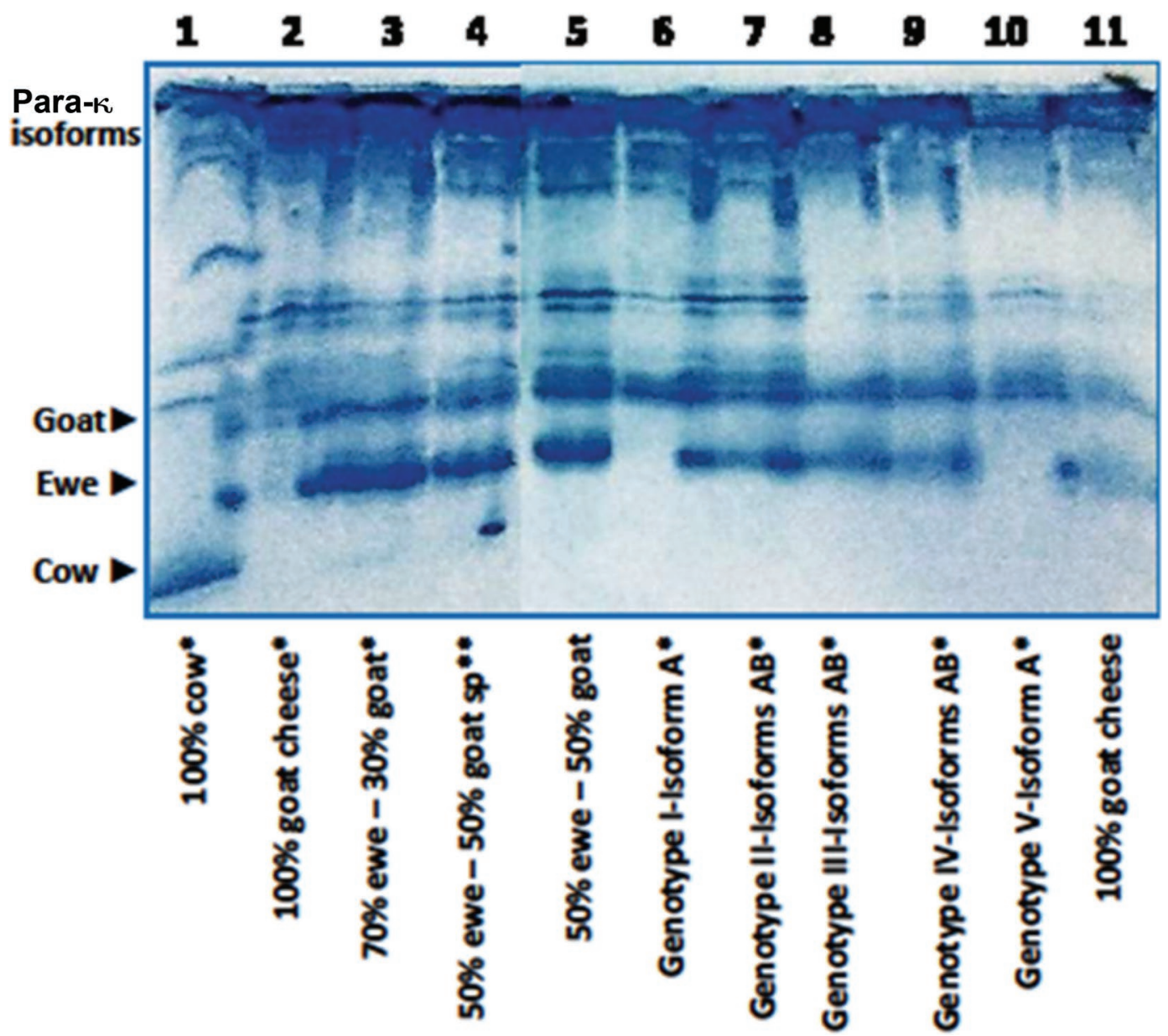

Figure 2. Isoelectric focusing analysis of para-k-CN isoforms out according to the official German method L01.00-39 ( $\$ 64$ LFGB; German Central Food and Feed Law Book, 2005). Lanes 1 and 3 to 5 correspond to control casein samples isolated by the procedure of Reg. 273/08 (Commission Regulation, 2008) from 100\% cow milk cheese, from feta Protected Designation of Origin cheese (70\% ewe, $30 \%$ goat), and the reference material BCR 599 (50\% ewe, 50\% goat provided by Joint Research Centre, Institute for Reference Materials and Measurements, European Commission's science and knowledge service). Additionally, a cheese sample produced from $100 \%$ goat milk and misidentified as adulterated was analyzed (lane 11, as well as lanes 10-11 in Supplementary Figure S1; https://doi.org/10.3168/jds.2016-11677). Lanes 6 to 10 correspond to milk samples from individuals Greek goats of known genetic profile, analyzed within the present study which correspond to genotypes I, II, III, IV, and VI. An asterisk $(*)$ denotes samples spiked with BCR 599; double asterisk $(* *)$ denotes sample spiked with $100 \%$ cow casein according to the procedure of isoelectric focusing method of Annex IX Reg 273/2008 (Commission Regulation, 2008). Color version available online.

Table 3. Observed genotypes, frequencies ${ }^{1}$ per region (Thessaloniki, Kilkis, and Serres), and total frequencies as well as isoform pattern produced from each genotype

\begin{tabular}{lccccc}
\hline Observed genotype & Thessaloniki & Kilkis & Serres & Average frequency $^{2}$ & IEF isoform \\
\hline Genotype I (1/1) & 0.28 & 0.35 & 0.37 & 0.333 & $\mathrm{~A} / \mathrm{A}$ \\
Genotype II (1/2) & 0.50 & 0.24 & 0.12 & $\mathbf{0 . 2 8 7}$ & $\mathrm{A} / \mathrm{B}$ \\
Genotype III (1/3) & 0.13 & 0.35 & 0.35 & 0.277 & $\mathrm{~A} / \mathrm{A}$ \\
Genotype IV (1/4) & 0.03 & 0.00 & 0.04 & $\mathbf{0 . 0 2 4}$ & $\mathrm{A} / \mathrm{B}$ \\
Genotype V (1/6) & 0.00 & 0.03 & 0.00 & $\mathbf{0 . 0 1 0}$ & $\mathrm{A} / \mathrm{B}$ \\
Genotype VI (2/3) & 0.06 & 0.00 & 0.00 & $\mathbf{0 . 0 2 0}$ & $\mathrm{B} / \mathrm{A}$ \\
Genotype VII $(2 / 5)$ & 0.00 & 0.00 & 0.04 & $\mathbf{0 . 0 1 3}$ & $\mathrm{B} / \mathrm{A}$ \\
Genotype VIII $(3 / 3)$ & 0.00 & 0.00 & 0.04 & 0.013 & $\mathrm{~A} / \mathrm{A}$ \\
Genotype IX (3/4) & 0.00 & 0.00 & 0.04 & $\mathbf{0 . 0 1 3}$ & $\mathrm{A} / \mathrm{B}$ \\
Genotype X (3/5) & 0.00 & 0.03 & 0.00 & 0.010 & $\mathrm{~A} / \mathrm{A}$ \\
\hline
\end{tabular}

${ }^{1}$ Frequencies were calculated manually using $f i=2 \mathrm{Ho}+\mathrm{He} / 2 \mathrm{~N}$. fi $=$ allele frequency; Ho = homozygous genotypes; $\mathrm{He}=$ heterozygous genotypes; $\mathrm{N}=$ number of individuals.

${ }^{2}$ Average frequencies in bold correspond to isoform B production according to observed genotype. 
Greek indigenous and Skopelos breeds in relation to European and African ones.

\section{Problematic Alleles in Greek and Non-Greek Goat Breeds}

The authenticity of dairy products constitutes a major issue mostly concerning customers' satisfaction and protection, as well the actual economic value of the product (Haza et al., 1999). Additionally, the misidentification of $100 \%$ goat cheese as being adulterated or mislabeled has both economic and legal consequences for the dairy industry, and particularly for Greece. Authentication of Greek goat dairy products using IEF of para- $\kappa-\mathrm{CN}$ peptide or other methods that are based on charge differences of para- $\kappa-\mathrm{CN}$, has previously led to erroneous results (Triantafillidou et al., 2011). As proven by the current work, this is related to goat $\mathrm{k}-\mathrm{CN}$ gene polymorphisms within Greek goat breeds. It is specifically correlated with nonsynonymous nucleotide point mutations in exon IV that alter the isoelectric point of caprine para-k-CN peptides $(\mathrm{pI}=5.29)$. The alleles carrying these mutations are responsible for the production of isoform $\mathrm{B}$, which resembles the ewe para-k-CN peptide ( $\mathrm{pI}=5.66)$ with regard to its mobility in IEF. Three different alleles carrying isoform B-producing mutations were identified (Table 2).

Although only allele 2 (allele D of CSN3) appears with considerable frequency, its presence in heterozygous condition increases the occurrence of the problematic genotypes significantly. The total frequency of the genotypes carrying these nucleotide substitutions is moderate to high in the herds sampled, ranging from 0.24 in Serres to 0.59 in the prefecture of Thessaloniki (Table 3). In total, $36.7 \%$ of samples analyzed in the current study would produce a false positive result using the IEF method.

Alleles D, M, and E, which correspond to $\mathrm{IEF}^{\mathrm{B}}$ group protein variants are not only present among the Greek goat breeds, but among other European and non-European goat breeds as well. Allele D of CSN3 is distributed among numerous wild and domestic goats according to Jann et al. (2004), but the frequencies vary considerably among different goat breeds. It is present among Italian goat breeds, as previously described, with considerable frequencies (Yahyaoui et al., 2001; Chessa et al., 2003; Reale et al., 2005), and also in the German breed Weisse Deutsche Edelziege (0.047; Prinzenberg et al., 2005). Furthermore, Turkish breeds, such as Angora (0.116) and Hair goat (0.250), show high frequencies of CSN3 allele D (Prinzenberg et al., 2005).

Genetic variant $\mathrm{E}$ was identified for the first time by Angiolillo et al. (2002). The Italian breed Montefalcone is characterized by its dominant presence, whereas it is absent from other Italian, Spanish, and French breeds analyzed (Yahyaoui et al., 2001).

Allele M appears at low frequency $(0.017)$ but can still create the same identification problems as alleles $\mathrm{D}$ and E. Thus far, it has not been reported for other European goat breeds, but only for African breeds at low frequencies (Prinzenberg et al., 2005; Kiplagat et al., 2010).

Based on our observations, the existence of goat $\kappa-\mathrm{CN}$ genetic variants that cause species identification problems for dairy products does not constitute an exclusively Greek issue. Isoelectric focusing is unable to distinguish goat and ewe dairy products, especially for some Greek breeds where composite genotypes characterize the majority of individuals' genetic profile according to this survey, but also for other European (including German ones) and non-European goat breeds. Consequently, a new method should be established for the differentiation between the 2 species instead of IEF, which is currently the official German method.

\section{New Approaches to Dairy Products Traceability- PCR-Based Species Detection}

Various protein methods, such as IEF, ELISA, and chromatographic methods, are widely used for species origin verification of dairy products (Hurley et al., 2004; Enne et al., 2005; Mayer, 2005; Xue et al., 2010), but they are neither very sensitive nor appropriate for the analyses of processed or more complex products in general. Regarding the immunological methods, ELISA is widely preferred for milk analysis as an inexpensive, fast, and high-sensitivity process (Bottero et al., 2003; Giovannacci et al., 2004). Several approaches have been attempted to detect goat milk in sheep milk (Costa et al., 2008; Zeleňáková et al., 2008), but they have not been found to be appropriate for cheese or heattreated milk samples. Consequently, quality evaluation of the method is required for traceability concerning processed and mixed dairy products.

Methods based on DNA are considered to be more suitable, reliable, and sensitive for species identification of dairy products because of the stability of DNA for products that are processed, heat-treated, or pasteurized (Pirondini et al., 2010). Because the $\kappa-\mathrm{CN}$ gene polymorphism complicates the species origin identification at the protein level, species genetic traceability probably constitutes the most appropriate solution. Mitochondrial DNA is the preferred PCR target, because of its abundance and higher mutation rate compared with nuclear DNA, to differentiate closely related species, even with low quality and quantity of DNA extracted from animal products (Lockley and Bardsley, 
2000; Pereira et al., 2012). Concerning mitochondrial genes, Cytochrome b amplification in combination with RFLP methods has been carried out to detect species origin of dairy products (Branciari et al., 2000); however, it is not very reliable to differentiate cow, goat, and ewe in complex dairy products (Bottero et al., 2003; Meyer et al., 1995).

Bottero et al. (2003) proposed a multiplex PCR method using the $12 \mathrm{~S}$ and $16 \mathrm{~S}$ rRNA genes to detect bovine, ovine, and caprine simultaneously, where specific primers were designed with different amplicon length for each species. As a result, easy, cheap, accurate, and simultaneous identification of the target species can be achieved with a good sensitivity threshold $(0.5 \%)$ in milk and cheeses instead of IEF. Recently, Tortorici et al. (2016) described a sensitive speciesspecific duplex-PCR method to detect cow, ewe, and goat dairy products simultaneously, amplifying $12 \mathrm{~S}$ and $16 \mathrm{~S}$ rRNA genes with $0.1 \%$ threshold. The speciesspecific primers were tested in Italian breeds for both studies, so possible nucleotide polymorphisms between the different goat breeds should be taken into account, as they could affect PCR amplification success. Future genetic research concerning the polymorphism of mitochondrial genes of Greek goat breeds could be helpful for designing species specific primers for the detection of species origin and quantification of their percentages in dairy products. This study also proposes an accurate and simple method for goat and ewe discrimination based on $\kappa-\mathrm{CN}$ gene amplification and sequencing. Alternatively, based on our findings, the method could go deeper than species differentiation and even trace geographical or genetic origin in some cases, as well as serve for the enhancement of the species by selective breeding, as certain $\kappa$-CN alleles are shown to be connected with quantitative traits, such as increased milk production, protein content, and so on (Deb et al., 2014).

In conclusion, PCR methods have proven to be more accurate and less time-consuming for traceability in the dairy industry and they could be standardized to reinforce the current legislation, taking into account the genetic polymorphism of the totality of different caprine and ovine breeds.

\section{ACKNOWLEDGMENTS}

This work was made possible due to financial support from MEVGAL SA Dairy Company. Farmers that have supplied samples are gratefully acknowledged. We also thank the Chemical State Laboratory Ioannina Division for supplying reference materials for IEF.

\section{REFERENCES}

Angiolillo, A., M. H. Yahyaoui, A. Sánchez, F. Pilla, and J. M. Folch. 2002. Short communication: Characterization of a new genetic variant in the caprine k-casein gene. J. Dairy Sci. 85:2679-2680. https://doi.org/10.3168/jds.S0022-0302(02)74353-1.

Borkova, M., and J. Snaselova. 2005. Possibilities of different animal milk detection in milk and dairy products - a review. Czech J. Food Sci. 23:41-50.

Bottero, M. T., T. Civera, D. Nucera, S. Rosati, P. Sacchi, and R. M. Turi. 2003. A multiplex polymerase chain reaction for the identification of cows', goats' and sheep's milk in dairy products. Int. Dairy J. 13:277-282. https://doi.org/10.1016/S0958-6946(02)00170-X.

Bramanti, E., C. Sortino, M. Onor, F. Beni, and G. Raspi. 2003. Separation and determination of denatured as1-, as2-, b- and kcaseins by hydrophobic interaction chromatography in cows', ewes' and goats' milk, milk mixtures and cheeses. J. Chromatogr. A 994:59-74

Branciari, R., I. J. Nijman, M. E. Plas, E. Di Antonio, and J. A. Lenstra. 2000. Species origin of milk in Italian mozzarella and Greek feta cheese. J. Food Prot. 63:408-411.

Caroli, A., O. Jann, E. Budelli, P. Bolla, S. Jäger, and G. Erhardt 2001. Genetic polymorphism of goat kappa-casein (CSN3) in different breeds and characterization at DNA level. Anim. Genet. $32: 226-230$.

Chessa, S., E. Butelli, K. Gutscher, A. Caroli, and G. Erhardt. 2003. Short communication: Simultaneous identification of five $\kappa$-casein (CSN3) alleles in domestic goat by polymerase chain reactionsingle strand conformation polymorphism. J. Dairy Sci. 86:37263729. https://doi.org/10.3168/jds.S0022-0302(03)73978-2.

Coll, A., J. M. Folch, and A. Sanchez. 1993. Rapid communication: Nucleotide sequence of the goat $\kappa$-casein cDNA. J. Anim. Sci. $71: 2833$.

Commission Regulation. 2008. (EC) No. 273/2008, OJ L 88, 29.3.2008, p.1.

Costa, N., F. Ravasco, R. Miranda, M. Duthoit, and L. B. Roseiro. 2008. Evaluation of a commercial ELISA method for the quantitative detection of goat and cow milk in ewe milk and cheese. Small Rumin. Res. 79:73-79. https://doi.org/10.1016/j. smallrumres.2008.07.012.

Deb, R., S. Kumar, R. Singh, G. Sengar, and A. Sharma. 2014. Genetic polymorphism and association of kappa-casein gene with milk production traits among Frieswal (HF X Sahiwal) cross breed of Indian origin. Iran. J. Vet. Res. 15:406-408.

Di Gerlando, R., L. Tortorici, M. T. Sardina, G. Monteleone, S. Mastrangelo, and B. Portolano. 2015. Molecular characterisation of k-casein gene in Girgentana dairy goat breed and identification of two new alleles. Ital. J. Anim. Sci. 14:3464. https://doi. org/10.4081/ijas.2015.3464.

Di Luccia, A., R. Mauriello, L. Chianese, L. Moio, and F. Addeo. 1990. K-casein polymorphism in caprine milk. Sci. Tecn. Latt. Casearia 41:305-314.

Enne, G., D. Elez, F. Fondrini, I. Bonizzi, M. Feligini, and R. Aleandri. 2005. High-performance liquid chromatography of governing liquid to detect illegal bovine milk's addition in water buffalo Mozzarella: Comparison with results from raw milk and cheese matrix. J. Chromatogr. A 1094:169-174. https://doi.org/10.1016/j. chroma.2005.09.004.

Furet, J. P., J. C. Mercier, S. Soulier, P. Gaye, D. Hue-Delahaie, and J. L. Vilotte. 1990. Nucleotide sequence of ovine $\kappa$-casein cDNA. Nucleic Acids Res. 18:17.

German Central Food and Feed Law Book. 2005. (Lebensmittel-, Bedarfsgegenstaende-und Futtermittelgesetzbuch - LFGB). L01.00$39 \S 64$.

Giovannacci, I., C. Guizard, M. Carlier, V. Duval, J. L. Martin, and C. Demeulemester. 2004. Species identification of meat products by ELISA. Int. J. Food Sci. Technol. 39:863-867. https://doi. org/10.1111/j.1365-2621.2004.00859.x.

Gupta, S. C., D. Kumar, A. Pandey, G. Malik, and N. Gupta. 2009. New k-casein alleles in Jakhrana goat affecting milk pro- 
cessing properties. Food Biotechnol. 23:83-96. https://doi. org $/ 10.1080 / 08905430802672079$.

Hall, T. A. 1999. BioEdit: A user-friendly biological sequence alignment editor and analysis program for Windows 95/98/NT. Nucleic Acids Symp. Ser. 41:95-98.

Haza, A. I., P. Morales, R. Marti, T. Garci, G. Anguita, and P. E. Herna. 1999. Detection and quantification of goat's cheese in ewe's cheese using a monoclonal antibody and two ELISA formats. J. Sci. Food Agric. 79:1043-1047.

Hurley, I. P., R. C. Coleman, H. E. Ireland, and J. H. Williams. 2004. Measurement of bovine IgG by indirect competitive ELISA as a means of detecting milk adulteration. J. Dairy Sci. 87:543-549. https://doi.org/10.3168/jds.S0022-0302(04)73195-1.

Jann, O. C., E. M. Prinzenberg, G. Luikart, A. Caroli, and G. Erhardt. 2004. High polymorphism in the -casein (CSN3) gene from wild and domestic caprine species revealed by DNA sequencing. J. Dairy Res. 71:188-195. https://doi.org/10.1017/S0022029904000093.

Kaiser, K. P., and I. Krause. 1985. Analytik von proteinen in lebensmitteln mit elektrophoretischen und chromatographischen verfahren. Z. Lebensm. Unters. Forsch. 180:181-201.

Kearse, M., R. Moir, A. Wilson, S. Stones-Havas, M. Cheung, S. Sturrock, S. Buxton, A. Cooper, S. Markowitz, C. Duran, T. Thierer, B. Ashton, P. Meintjes, and A. Drummond. 2012. Geneious basic: An integrated and extendable desktop software platform for the organization and analysis of sequence data. Bioinformatics 28:1647-1649. https://doi.org/10.1093/bioinformatics/bts199.

Kiplagat, S. K., M. Agaba, I. S. Kosgey, M. Okeyo, D. Indetie, O. Hanotte, and M. K. Limo. 2010. Genetic polymorphism of kappacasein gene in indigenous Eastern Africa goat populations. Int. J. Genet. Mol. Biol. 2:001-005.

Librado, P., and J. Rozas. 2009. DnaSP v5: A software for comprehensive analysis of DNA polymorphism data. Bioinformatics 25:14511452. https://doi.org/10.1093/bioinformatics/btp187.

Lockley, A. K., and R. G. Bardsley. 2000. DNA-based methods for food authentication. Trends Food Sci. Technol. 11:67-77. https:// doi.org/10.1016/S0924-2244(00)00049-2.

Mayer, H. K. 2005. Milk species identification in cheese varieties using electrophoretic, chromatographic and PCR techniques. Int. Dairy J. 15:595-604. https://doi.org/10.1016/j.idairyj.2004.10.012.

Mayer, H. K., D. Heidler, and C. Rockenbauer. 1997. Determination of the percentages of cows', ewes' and goats' milk in cheese by isoelectric focusing and cation-exchange HPLC of $\gamma$ - and para-k-caseins. Int. Dairy J. 7:619-628.

Mercier, J. C., F. Addeo, and J. P. Pelissier. 1976. Structure primaire de la caseinomacropeptide caprine. Biochimie 58:1303-1310. https://doi.org/10.1016/S0300-9084(77)80013-8.

Meyer, R., C. Höfelein, J. Lüthy, and U. Candrian. 1995. Polymerase chain reaction-restriction fragment length polymorphism analysis: A simple method for species identification in food. J. AOAC Int. 78:1542-1551.

Moioli, B., F. Pilla, and C. Tripaldi. 1998. Detection of milk protein genetic polymorphisms in order to improve dairy traits in sheep and goats: A review. Small Rumin. Res. 27:185-195. https://doi. org/10.1016/S0921-4488(97)00053-9.

Othman, O. E., S. A. El-Fiky, N. A. Hassan, E. R. Mahfouz, and E. A. Balabel. 2013. Genetic variations of $\beta$ - and $\kappa$-casein genes in Egyptian sheep breeds. J. Appl. Biosci. 64:4858-4866. https://doi. org/10.4314/jab.v64i1.88475.

Pariset, L., A. Cuteri, C. Ligda, P. Ajmone-Marsan, and A. Valentini. 2009. Geographical patterning of sixteen goat breeds from Italy, Albania and Greece assessed by single nucleotide polymorphisms. BMC Ecol. 9:20. https://doi.org/10.1186/1472-6785-9-20.

Pereira, F., J. Carneiro, and B. van Asch. 2012. A guide for mitochondrial DNA analysis in non-human forensic investigations. Open Forensic Sci. J. 3:33-44. https://doi.org/10.2174/1874402801003 010033.

Pirondini, A., U. Bonas, E. Maestri, G. Visioli, M. Marmiroli, and N. Marmiroli. 2010. Yield and amplificability of different DNA extrac- tion procedures for traceability in the dairy food chain. Food Contr. 21:663-668. https://doi.org/10.1016/j.foodcont.2009.10.004.

Prinzenberg, E. M., K. Gutscher, S. Chessa, A. Caroli, and G. Erhardt. 2005. Caprine kappa-casein (CSN3) polymorphism: new developments in molecular knowledge. J. Dairy Sci. 88:1490-1498. https://doi.org/10.3168/jds.S0022-0302(05)72817-4.

Reale, S., M. H. Yahyaoui, J. M. Folch, A. Sanchez, F. Pilla, and A. Angiolillo. 2005. Genetic polymorphism of the k-casein (CSN3) gene in goats reared in Southern Italy. Ital. J. Anim. Sci. 4:97-101.

Romero, C., O. Perez-Andujar, A. Olmedo, and S. Jimenez. 1996. Detection of cow's milk in ewe's or goat's milk by HPLC. Chromatographia 42:181-184.

Sacchi, P., S. Chessa, E. Budelli, P. Bolla, G. Ceriotti, D. Soglia, R. Rasero, E. Cauvin, and A. Caroli. 2005. Casein haplotype structure in five Italian goat breeds. J. Dairy Sci. 88:1561-1568. https://doi. org/10.3168/jds.S0022-0302(05)72825-3.

Sambrook, J., E. F. Fritsch, and T. Maniatis. (1989). Molecular Cloning: A Laboratory Manual. Cold Spring Harbor Laboratory Press, Cold Spring Harbor, NY.

Scheet, P., and M. Stephens. 2006. A fast and flexible statistical model for large-scale population genotype data: Applications to inferring missing genotypes and haplotypic phase. Am. J. Hum. Genet. 78:629-644. https://doi.org/10.1086/502802.

Stephens, M., N. J. Smith, and P. Donnelly. 2001. A new statistical method for haplotype reconstruction from population data. Am. J. Hum. Genet. 68:978-989. https://doi.org/10.1086/319501.

Strange, E. D., E. L. Malin, D. L. Van Hekken, and J. J. Basch. 1992. Chromatographic and electrophoretic methods used for analysis of milk proteins. J. Chromatogr. 624:81-102. https://doi. org/10.1016/0021-9673(92)85675-J.

Tortorici, L., R. Di Gerlando, M. Tolone, and S. Mastrangelo. 2016. 12S rRNA mitochondrial gene as marker to trace Sicilian mono-species dairy products. Livest. Sci. 193:39-44. https://doi.org/10.1016/j. livsci.2016.09.015

Triantafillidou, D., P. Tarantili, G. Triantaphyllidis, and E. Georgakis. (2011). Para-k-casein profiles of Greek caprine cheese: Their genetic origin and influence on the detection of adulteration using isoelectric focusing. IDF International Symposium on Sheep, Goat and Other Non-Cow Milk, Athens. International Dairy Federation (INPA), Brussels, Belgium.

Wang, L., and Y. Xu. 2003. Haplotype inference by maximum parsimony. Bioinformatics 19:1773-1780. https://doi.org/10.1093/ bioinformatics/btg239.

Wedholm, A., L. B. Larsen, H. Lindmark-Månsson, A. H. Karlsson, and A. Andrén. 2006. Effect of protein composition on the cheesemaking properties of milk from individual dairy cows. J. Dairy Sci. 89:3296-3305. https://doi.org/10.3168/jds.S0022-0302(06)723669.

Xia, X., and Z. Xie. 2001. DAMBE: Software package for data analysis in molecular biology and evolution. J. Hered. 92:371-373. https:// doi.org/10.1093/jhered/92.4.371.

Xue, H., W. Hu, H. Son, Y. Han, and Z. Yang. 2010. Indirect ELISA for detection and quantification of bovine milk in goat milk. Int. J. Food Sci. Technol. 31:370-373.

Yahyaoui, M. H., A. Angiolillo, F. Pilla, A. Sanchez, and J. M. Folch. 2003. Characterization and genotyping of the caprine kappa-casein variants. J. Dairy Sci. 86:2715-2720. https://doi.org/10.3168/jds. S0022-0302(03)73867-3.

Yahyaoui, M. H., A. Coll, A. Sanchez, and J. M. Folch. 2001. Genetic polymorphism of the caprine kappa casein gene. J. Dairy Res. 68:209-216.

Zachar, P., M. Šoltés, R. Kasarda, J. Novotný, M. Novikmecová, and D. Marcinčáková. 2011. Analytical methods for the species identification of milk and milk products. Mljekarstvo 61:199-207.

Zeleňáková, L., J. Golian, and P. Zajác. 2008. Application of ELISA tests for the detection of goat milk in sheep milk. Milchwissenschaft 63:137-141. 